\title{
APRESENTAÇÃO
}

\section{Formação continuada e práticas formadoras}

\section{A}

Lei de Diretrizes e Bases da Educação Nacional (1996), as Diretrizes Curriculares Nacionais para a Formação de Professores da Educação Básica (2000) e o Plano Nacional de Educação 2014 (PNE), sob os auspícios dos organismos internacionais, que passam a exercer forte influência na reestruturação da educaçáo dos países periféricos a partir dos anos 1990, legislam, dentre outros aspectos, sobre a formação continuada de professores da Educação Básica, compreendida pela Educação Infantil, Ensino Fundamental e Médio.

Decorrentes deste conjunto de documentos chegam às escolas projetos, programas e materiais, visando à reprodução de um ensino inscrito em tendências pedagógicas não críticas, sejam estas tradicionais ou tecnicistas, que desconsideram professores e alunos como sujeitos sociais. Corrobora para a implementação das políticas educacionais o forte aparato tecnológico que, presente ou não nas escolas, encerra a promessa de que as tecnologias da informação e da comunicação são recursos indispensáveis para uma nova educação, para a modernização da escola e para a qualificação dos professores, ao instituírem novos paradigmas à educaçáo brasileira.

A precarização do trabalho docente, decorrente da formação e de condiçóes de trabalho adversas, aposta na formação continuada, não pela necessidade de permanente formação inerente a todas as profissóes que pretendam acompanhar as demandas por mudanças da sociedade, bem como a produção de novos conhecimentos, mas, antes disso, como forma de treinamento/capacitação e até mesmo em cursos ditos de reciclagem. Tal formação atribui aos professores a função de administrar 
práticas pedagógicas oriundas de programas verticalizados, como mero executores de planos e programas preestabelecidos, retirando de seu trabalho a dimensão de cientista e pesquisador da educação. Dito de outra forma, os professores têm sido alijados de desenvolver seu trabalho junto a seus alunos, planejando a partir de demandas de contextos específicos e coletivos, com autonomia, conhecimento e crítica no seu fazer pedagógico.

$\mathrm{Na}$ esteira destas propostas a precarização vem sendo disseminada e naturaliza a formação a partir de estratégias reguladoras de demandas externas ao trabalho docente, o que contribui para a despolitização das práticas educativas. Embora essa despolitizaçáo esteja presente, com maior ou menor intensidade, também é possível constatar pelas mãos de muitos educadores a luta pela formação continuada como um direito do professor na direção do aprimoramento do trabalho pedagógico e da articulação entre conhecimento e desenvolvimento profissional. Com base nessas consideraçóes, procuramos alinhavar os artigos que compóem esse Caderno, focalizando o debate acadêmico que valoriza a formação docente na perspectiva crítica para dar suporte a difícil tarefa de renovar para resistir. Assim, o conjunto de trabalhos apresentados reflete sobre as políticas educacionais que delineiam o cenário da formação e trabalho docente no Brasil e suas implicaçóes no processo de ensino-aprendizagem no âmbito da Educação Básica.

No primeiro artigo as autoras Ligia Karam Corrêa de Magalhães e Leny Cristina Soares Souza Azevedo, ambas da Universidade Federal do Rio de Janeiro (UFRJ), discutem a inversão no foco conferido à formação de professores, que migra da formação inicial de qualidade, produzidas a partir de contextos específicos, com vistas a processos emancipatórios e passa a operar no âmbito da formação continuada, estabelecendo distância entre a produção do conhecimento e a transmissão e sua transformação em senso comum. As autoras tomam como ponto de partida a análise de documentos que legislam sobre a formação continuada de professores, com ênfase no Plano Nacional de Educação, o PNE.

O olhar histórico da formação de professores no Brasil nos aponta para um deslocamento de interesses do poder público. O grande investimento em formação continuada e o aligeiramento da formação 
inicial são discutidos no segundo artigo pelos Professores da UFRJ, Marcelo Macedo Corrêa e Castro e Rejane Maria de Almeida Amorim. Nesse estudo os autores, além de revisitarem o conceito de formação continuada, defendem a superaçáo (a ruptura) da precarização da formação oferecida aos professores como sendo reparadora/supletiva, em busca de uma formação eletiva.

Pensar em uma formação mais humanizada, voltada para a compreensão do educador como sujeito, significa recolocar o "professor real" no centro da discussão, considerando que todas as esferas de sua vida constituem seu processo de formação. Abordando essa temática, os professores da UFPE, Clarissa Martins de Araújo, Everson Melquíades Araújo e Rejane Dias da Silva discutem no terceiro artigo a contribuição da teoria crítica da formaçáo humana para os processos de formação continuada de professores na contemporaneidade, contrapondo-se às estratégias que arquitetam um novo perfil profissional de professor a partir dos anos 1990, mas que na prática não conferiram mudanças significativas na formação docente.

$\mathrm{O}$ quarto artigo apresenta a contribuição internacional da Professora Carmen de Jesus Dores Cavaco, da Universidade de Lisboa, que trata da formação de professores na perspectiva de superação do distanciamento entre a vida do educador e sua vida acadêmica. Através da abordagem biográfica, o educador é o centro do processo formativo, sendo visto como autor e produtor de conhecimento.

Seguindo a perspectiva apresentada por Cavaco, a Professora Beatriz Maria Eckert-Hoff, do Centro Universitário do Distrito Federal (UDF), discute no quinto artigo o dizer do sujeito-professor e nos apresenta a pesquisa realizada com educadores em formação, do Estado de Santa Catarina e da cidade de Campinas, Estado de São Paulo. O estudo está focado em seus relatos autobiográficos, trazendo à tona o "falar de si" no processo de construção da subjetividade dos educadores via história de vida.

No último e sexto artigo, a Professora Maria Izabel de Bortoli Hentz, da Universidade Federal de Santa Catarina (UFSC), apresenta uma análise dos efeitos de cursos de formação continuada na prática 
docente. Por meio de um estudo de caso, a autora evidencia significativa mudança no trabalho com o texto na aula de Língua Portuguesa.

O Caleidoscópio traz o relato de experiência da Professora Arlene de Paula Lopes Amaral, da Universidade Federal de Viçosa (UFV), a partir de seu trabalho no "Pacto Nacional pela Alfabetização na Idade Certa" (PNAIC). A autora sintetiza a prática nacional de políticas públicas para formaçáo continuada no Brasil e identifica situaçóes que vão na contramão de uma formação subjetiva e reforçadora de autoria.

Neste jogo de forças observa-se a necessidade cada vez mais premente de se realizarem estudos investigativos para favorecer discussões acerca da educação nacional e seus possíveis caminhos no que diz respeito à formação continuada de professores. Com esse propósito os autores dos seis artigos e do caleidoscópio revisitam conceitos, práticas, tendências, políticas educacionais, conflitos dentre outros que revelam a opção por questóes cruciais que convidam ao combate à inação e ao não-envolvimento, enfatizando uma prática que dê respostas a alguns problemas existentes a partir de uma construção coletiva (nós-eu) na qual devem comprometer-se diferentes açóes.

Rejane Maria de Almeida Amorim

Ligia Karam Corrêa de Magalhães

Organizadoras

DOI: http://dx.doi.org/10.1590/CC0101-32622015 